\title{
Nuptiality and Marital Fertility during the First Phase of Industrialization in Finland ${ }^{1}$
}

\author{
By JARL LINDGREN
}

The Population Research Institute

In preindustrial Western European societies nuptiality was an important factor affecting population growth. Procreation almost wholly occurred within wedlock and nuptiality determined the overall fertility. The age at marriage was high compared with the modern marriage pattern. The origin of and the reasons for late marriage are probably to be found as Hajnal has pointed out (1965) in the economic system with e.g. small holdings occupied by a single family. A man had to postpone marriage until he could establish an independent livelihood and had adequate means to support a family. In Western Europe marriage was not only contracted late but was also far from universal. Eastern Europe, on the contrary, displayed a quite different marriage pattern with a small proportion of single persons, especially of women and a considerably lower age at marriage. The Finnish marriage pattern is generally considered to take an intermediary position between Western and Eastern Europe so that features of the Eastern European pattern grow more visible towards the eastern parts of the country.

The modernization of the nuptiality pattern, usually linked with industrialization, signified earlier and more universal nuptiality. Along with the Industrial Revolution the economic and demographic functions of nuptiality diminished and gradually disappeared. The change from an agrarian society to an industrialized one, with a growing wage earning class, mortality decline and gradually extending control of marital fertility implied better opportunities to a growing number of people to marry but also to marry earlier than before.

In some studies it has been observed that changes in nuptiality and fertility have been more or less firmly linked together: e.g. in France a change in nuptiality occurred after marital fertility changed (Lesthaeghe 1977, 151). In the Netherlands the change in nuptiality is seen as a consequence of proletarization and the decline of an inheritance system based on primogeniture. Earlier marriage is supposed to have opened up a greater need for spacing births and for a shorter reproduction period (Hofstee 1954 in Lesthaeghe 1977, 66). It is likely, however, that nuptiality and fertility often are causally linked together. Both phenomena respond simultaneously to the same exogenous factors: industriali-

1 I am indebted to Kari Pitkänen for many valuable comments concerning the impact of historical development. 
zation and urbanization initiate changes in the society which simultaneously affect both nuptiality and fertility.

This article is an attempt to elucidate the changes in and the links between nuptiality and fertility during the first phase of industrialization in Finland i.e. the economic and social modernization which was a result of the Industrial Revolution. It should be emphasized, however, that the population changes during the first decades of Industrialization in Finland are to a great extent the consequence of the social changes in the countryside which implied a disproportionate growth of the landless population since the mid-1800s. The pressure caused by overpopulation was relieved by and by when industry grew larger and overseas emigration increased.

\section{The beginning of industrialization}

The beginning of industrialization in Finland is usually placed in the 1870 s. The take-off from the traditional society in the sense Rostow $(1971,7)$ refers to i.e. when economic growth became the normal condition of the society, began later, however, probably in the last decade of the 19th century. The criterion used by Mathias (1969, 2-3), the excess of two per cent's growth of the GNP, also justifies placing the outset of industrialization in the 1890 s when the annual growth of the GDP per capita exceeded two per cent (Hjerppe-Pihkala 1977).

However, the gross value of the production of agriculture, forestry, industry and handicraft began to grow continuously already in the beginning of the $1880 \mathrm{~s}$. The annual average growth of the GDP in the 1870 s and the 1880 s was about one per cent. The growth of the GDP began to accelerate in the $1890 \mathrm{~s}$ when it showed an average yearly increase of 3.9 per cent, and during the following decade it was 2.3 per cent (Hjerppe-Pihkala 1977, 315).

The demographic transition began considerably earlier than industrialization. A weak decreasing fertility and infant mortality trend had continued since the middle of the 18 th century but not until the 1880 s did the mortality decline become clearly visible. In the beginning of the 1900 s fertility also started to go down violently (Strömmer 1967, 46-50).

This study extends over the period 1880-1960. Attempts will, however, be made when statistical data are available, to include earlier years in the analysis. It is presumed that the year 1880 reflects the pattern of the traditional society. The end of the period is supposed to be the time when Finland reached the full maturity of industrialization and entered the mass consumption society.

Detailed statistics of nuptiality and fertility are not available on the national level earlier than 1880. Hence, it is not possible to obtain data on married women or contracted marriages by age groups before that. Specific information 
on marriages and births can, nevertheless, be collected from the parish register of marriages from the 18th century on. However, the collection of these data is burdensome and expensive as it means going through parish registers in parish provincial archives.

Consequently, in the following, national data is used mainly. However, in order to get a more specific picture of the phenomenon, some information is presented on the evolution of nuptiality and fertility in three local municipalities representing different occupational structures and different economic and social development. One of them is a rural community with a rapidly developing industry, the second one a fairly static agricultural society and the third one a smallish town where trade and service have always played an important role. The data collected is partly obtained from the population tables of these municipalities and partly from the parish records which are a kind of official parish register. This local data is derived from a family reconstruction study under preparation by the author concerning the change of family size during the first epoch of industrialization in Finland.

\section{Nuptiality on the national level}

Since the middle of the 18th century figures on the rate of ever-married persons can be obtained. The statistics show that this rate was slowly increasing all the time until the middle of the 19th century: in 1751 the proportion of married women was 65 per cent, in 1870 only 55 per cent. After this an increasing tendency was again visible. The reason for the decline is likely to be the growing overpopulation of landless people in rural communities and the worsening social circumstances following this population growth.

During the last two decades of the 19th century the rate of ever-married persons was fairly stable; about 51 per cent of all women in the childbearing period were married. A tendency to lower nuptiality was evident, however, during the first decade of the following century. This tendency strengthened noticably in the 1910 s; in 1920 only 44 per cent of all women aged 15-49 years were married. The decrease was most striking in the younger age-groups (Figure 1). Among the 15-19-year-olds the rate started to go down already in the 1890 s and in 1920 it was only half of what it was in 1880.

From 1930 on the proportion of married women went up and in 1960 it was much higher than ever before. This was especially visible in the youngest age group.

In order to compare the Finnish nuptiality trend especially with Western Europe the index of the proportion of married women developed by Coale was used. In this index, $I_{m}=\frac{\Sigma m_{i} F_{i}}{\Sigma w_{i} F_{i}}, m_{i}$ is the number of married women, 
Figure 1. Married women as a percentage of total women in reproductive age.

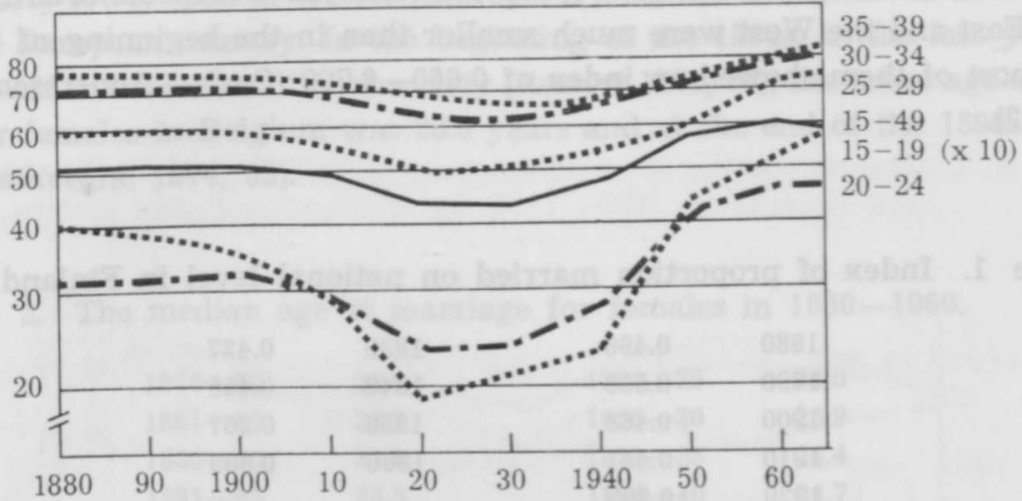

Source: Strömmer 1969, 46.

$\mathrm{w}_{\mathrm{i}}$ the total number of women, $\mathrm{F}_{\mathrm{i}}$ the marital fertility from the Hutterite schedule, and i stands for age groups (Coale 1965). ${ }^{2}$ This index gives a large weight to women in the most fertile years and summarizes the nuptiality pattern within the childbearing span by taking in consideration overall fertility. The number of children married women would bear, if they were subject to natural fertility, is compared with the number of children all women would bear under the same circumstances (Lesthaeghe 1977, 47). The value of $\mathrm{I}_{\mathrm{m}}$ is unity if all women are married but all the lower the later or less universal marriage is. This index as well as the index of marital fertility later computed in this article have been specially developed for the European fertility project and calculated for many European countries.

The proportion of married women according to the index $I_{m}$ shows a clearly decreasing tendency during the early stage of industrialization with a height of 0.500 in 1890 and shrinking to only 0.399 in 1920 . During the following decades the index goes up again steadily, so that in 1960 it was higher than ever or 0.605 (Table 1).

It appears from the work of Lesthaeghe $(1977,55)$ on Belgian fertility that the proportion of married in France in 1880 was 0.538 , in Germany 0.501 , in the Netherlands 0.469 and in Belgium as low as 0.435. During the following decades the proportion gradually increased in Belgium to 0.705 in 1961 or higher than in

2 The fertility of married Hutterite women by five-year age groups are $0.300,0.550$, $0.502,0.447,0.406,0.222,0.061$ starting at the age group of $15-19$ and ending with $45-$ 49 years. This is the highest schedule of fertility unaffected by contraception founded by Louis Henry (Coale 1965). This natural fertility is affected by physiological, biological and social factors e.g. frequency of intercourse; sexual taboos might reduce fertility but are not used as conscious methods of contraception. 
Finland. This was also the case in Germany although the change here was less accentuated. In the Netherlands and France the proportion of married remain rather stable. In 1960 the differences between the European countries both in the East and the West were much smaller than in the beginning of the century: most of them showed an index of 0.660-0.700 (Coale-Andersson-Härm 1979, 12).

$\mathrm{T} a \mathrm{ble}$ 1. Index of proportion married on national level in Finland.

$\begin{array}{llll}1880 & 0.498 & 1930 & 0.437 \\ 1890 & 0.500 & 1940 & 0.455 \\ 1900 & 0.468 & 1950 & 0.567 \\ 1910 & 0.461 & 1960 & 0.605 \\ 1920 & 0.399 & & \end{array}$

However, industrialization and economic growth started earlier in Western Europe than in Finland. For this reason the comparison has to be extended to the middle of the 19th century, when the Malthusian pattern of reproduction characterized the nuptiality of Western Europe. At that time the proportion of married was low, in Belgium 0.366 (1855) and in the Netherlands 0.389 (1850), and in Germany 0.454 (1865).

France showed a neo-Mathusian pattern with a rather high nuptiality rate but reduced marital fertility; in 1840 the proportion married was already 0.516 . The increase of nuptiality was discernible from the middle of the 19th century.

In 1900 in Eastern Europe, in Bulgaria, Poland, Hungary, and Russia the proportion married was about 0.700 . These countries represent regions where the industrial take-off apparently started later than in Finland. The Finnish pattern of nuptiality seems to follow its own path. The early figures of proportion married indicate an Eastern European pattern rather than a Western pattern.

The age at marriage and frequency of marriages generally behave in opposite directions: when nuptiality increases the age at marriage goes down. In the period $1880-1930$ the median age at marriage of women remained practically unchanged, however, or 23.5-24.0 years.

A weak declining tendency began at the end of the 19 th century, but it soon turned upwards again, reaching its peak at the end of the 1930s with an average age at marriage of 24.7 years. After the Second World War the average age declined again so that at the end of the period, in 1960, it was only 22.8 years (Table 2).

A comparison of the average age at marriage with other countries during the 19 th century is generally not possible using the median age. However, the 
mean age at marriage for women in their first marriage was 25.1 in $1881-90$, i.e. in the beginning of the industrialization of Finland (OSF VI, 41; III 1909, 101), clearly lower than in Western Europe, if Belgium is considered as a typical Western European country. In the beginning of the 1860 s, in the last years of the take-off from the traditional society (Rostow 1971, 38), the mean age at marriage for females in Belgium was 28.0 years and at the end of the 1890 s it was 25.7 (Lesthaeghe 1974, 53).

$\mathrm{Tab}$ le 2. The median age at marriage for females in $1880-1960$.

$\begin{array}{llll}1876-80 & 23.9 & 1921-25 & 24.0 \\ 1881-85 & 23.8 & 1926-30 & 23.9 \\ 1886-90 & 23.8 & 1931-35 & 24.4 \\ 1891-95 & 23.5 & 1936-40 & 24.7 \\ 1896-1900 & 23.5 & 1941-45 & 24.3 \\ 1901-05 & 23.5 & 1946-50 & 23.7 \\ 1906-10 & 23.6 & 1951-55 & 23.2 \\ 1911-15 & 23.7 & 1956-60 & 22.8 \\ 1916-20 & 24.0 & & \\ \text { Source: Strömmer 1969, } 44 .\end{array}$

There is no statistical information on the age at marriage before 1880 but the stability of the mean age at birth gives a view of the constancy of the marriage and fertility pattern. Mean age at birth was almost unchanged from 1865 to the middle of the 1890 s being 31.23 in $1866-70$ and 31.37 in $1886-90$ with a weak decreasing tendency during the 1870 s when it was 31.0 (OSF VI,41; 1909 120).

\section{Nuptiality on the local level}

The proportion of married women by age groups in the three municipalities studied seems to vary rather capriciously from time to time. This is at least partly a consequence of the fact that the absolute number of women is relatively small, totaling only some hundred per age group. Figure 2 shows the proportion of married women in five-year age groups from 20 to 45 years according to the census every tenth year. In Sysmä, which represents a stationary agrarian society, a remarkable decline was visible from 1900 to 1910 . This decline is reflected in all age groups. Even in Pohja, which represents a rural community with a fast growing industry, the same tendency was visible. The downward trend comes forth in Pohja but seems to turn upward in Sysmä again after 1910. The youngest age group, 20-24 years, showing the marriage pattern of the youngest generation displays in conformity with the national aver- 
age (c.f. Figure 1) a rather clear declining tendency in Pohja and Sysmä from 1900 to 1910 . In Hamina, a smallish town with few industries, the proportion of married women remained almost unchanged until $1930 .^{3}$

Figure 2. The proportion of married women aged 15-49 in Sysmä, Pohja and Hamina in 1880-1960, by quinquennial age groups.

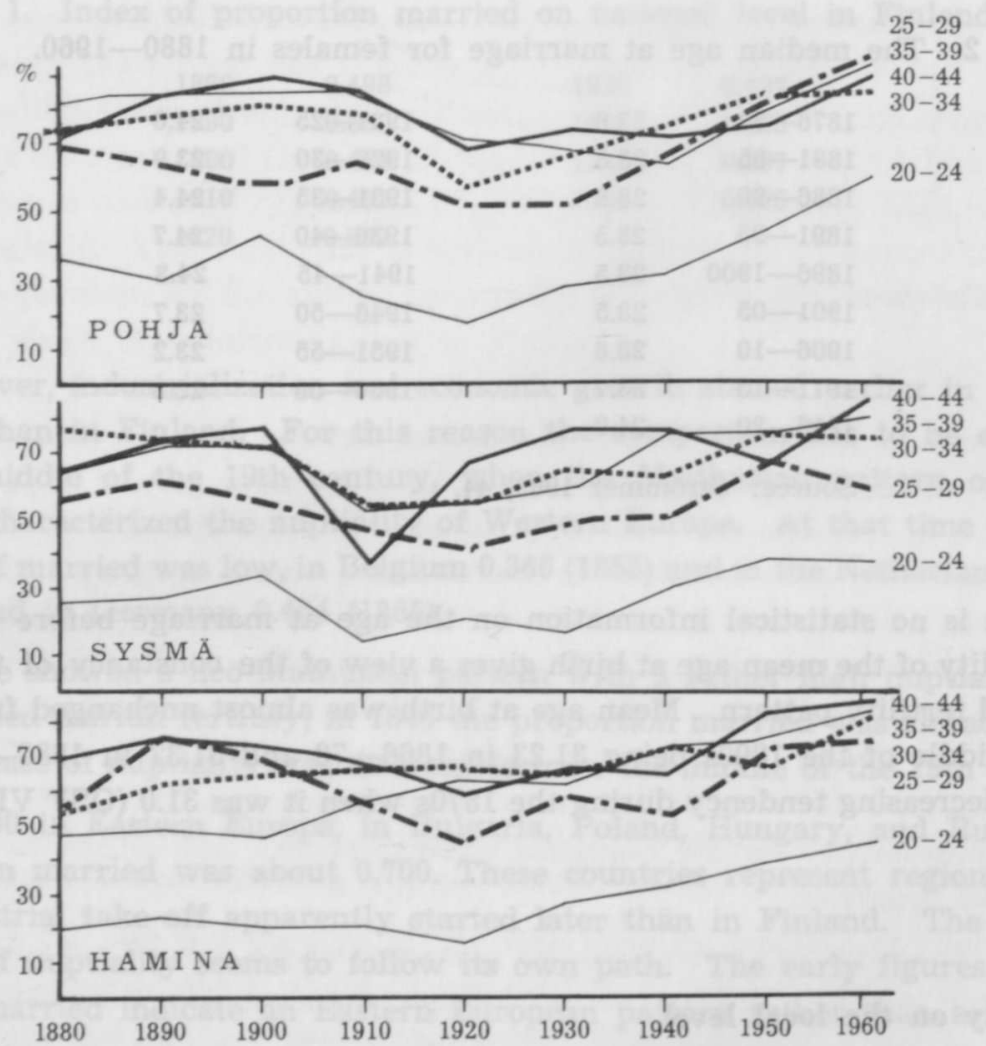

From 1940 on the proportion of married women goes up. The proportions married became even more similar in the three municipalities. The increase is especially accentuated in Hamina and among the young people, the $20-24$ year-olds.

The difference between Pohja and Sysmä could probably also be explained by their different economic structure. In Sysmä, where the population mainly

3 Sysmä is situated in the western part of the Province of Mikkeli, 40 kilometers north of the city of Lahti, Hamina in the Province of Kymi at the Eastern Finnish Gulf, 20 kilometers from the city of Kotka, and Pohja in the western part of the Province of Uusimaa, 20 kilometers north of Ekenäs. 
got their livelihood from agricultural occupations, the economically active within industry in 1920 was still as low as three per cent. In Pohja the corresponding percentage was 22 per cent already by 1860 and 33 per cent in 1920 .

The index $I_{m}$ of the proportion married in the three municipalities generally shows the same development as the national average. It should, however, be noted that the indices are somewhat lower in all three municipalities than the national average (Table 3). In 1880 the index $I_{m}$ was highest or 0.523 in Sysmä, lowest or 0.420 in Hamina.

$\mathrm{T}$ a b le 3. Index of proportion married in the municipalities of Pohja, Sysmä and Hamina.

$\begin{array}{lccc} & \text { Pohja } & \text { Sysmä } & \text { Hamina } \\ 1880 & 0.523 & 0.460 & 0.420 \\ 1890 & 0.551 & 0.470 & 0.513 \\ 1900 & 0.550 & 0.470 & 0.431 \\ 1910 & 0.521 & 0.358 & 0.474 \\ 1920 & 0.394 & 0.331 & 0.384 \\ 1930 & 0.453 & 0.384 & 0.425 \\ 1940 & 0.527 & 0.477 & 0.474 \\ 1950 & 0.643 & 0.482 & 0.596 \\ 1960 & 0.702 & 0.550 & 0.623\end{array}$

The average age at marriage in the three municipalities has been calculated for decennial cohorts and represents only mothers with children. Hence they are not quite comparable with national averages. This might explain why the local mean age at marriage in table 4 coincides very nearly with the median ages in table 2 . In reality the mean age used to be somewhat higher than the median age. Hence the ages calculated for the three local municipalities are visibly lower than national averages.

More interesting than a comparison with the national average is, however, an examination of the differences between municipalities and at time intervals. Highest age at marriage is displayed by Hamina, the urban municipality, and the smallest by Sysmä, the agrarian society. The tendency towards an earlier marriage at the end of the century is obvious at least in Pohja and Hamina. The great variation between cohorts is most probably a consequence of the small number of families studied, which was only 1500.

Somewhat astonishing is that the age at marriage in Sysmä as an agrarian community is rather low. This is still more strange as the families were represented by farm workers and landless population which in Finland are generally considered to have a late marriage pattern. The reason could be that Sysmä represents the Eastern European pattern of nuptiality; geographically Sysmä is situated in eastern Central Finland. 
As some small studies on nuptiality prove Finland is on the borderline between Western and Eastern Europe. The mean age for women at marriage around the 1840 s was 25.4 in Southern and Southwestern Finland and in Eastern Finland about one year lower or 24.5.4

Ta ble 4. Mean age at marriage for women by birth cohorts in Pohja, Sysmä and Hamina.

\begin{tabular}{lcccccc} 
& \multicolumn{2}{c}{ Pohja } & \multicolumn{2}{c}{ Sysmä } & \multicolumn{2}{c}{ Hamina } \\
$1830-39$ & Age & D & Age & D & Age & D \\
$1840-49$ & 24.1 & 4.8 & 22.4 & 3.1 & 26.1 & 5.9 \\
$1850-59$ & 23.8 & 4.0 & 21.6 & 2.9 & 24.8 & 5.9 \\
$1860-69$ & 23.3 & 3.5 & $\ldots$ & $\ldots$ & 26.1 & 6.3 \\
$1870-79$ & 23.2 & 4.8 & 22.2 & 4.0 & 25.2 & 4.2 \\
$1880-89$ & 23.9 & 3.5 & 24.4 & 5.2 & 25.1 & 5.0 \\
$1890-99$ & 22.8 & 3.0 & 22.2 & 3.6 & 24.3 & 4.3 \\
& 22.7 & 2.9 & 23.9 & 3.8 & 24.1 & 4.2
\end{tabular}

The relatively high age at marriage in Hamina is also reflected in Table 3 where Hamina represents the lowest proportion of married women. The connection between age at marriage and the proportion of married women for Pohja and Sysmä is not as distinct as for Hamina but is still visible.

\section{Fertility}

In the Finnish population statistics information on fertility has started earlier and has been more detailed than that on nuptiality. When examining the transition caused by industrialization this advantage is of less value, however, as the fertility decrease is a rather late phenomenon.

The crude birth rate already showed a downward tendency at the end of the 1800 s but measured with completed fertility the declining tendency was not visible until the beginning of the first decade of the 20th century. After 1910 the decline began to accelerate (Table 5).

In 1886-90 completed fertility was still 4.82 children per woman. During the following two decades completed fertility fell by more than two children, from 4.65 in $1906-10$ to 2.40 in $1931-35$.

4 The arithmetic mean age at marriage was 25.4 around 1840 in three rural municipalities of the Province of Turku and Pori (Airola 1971). In the province of Uusimaa a corresponding arithmetic mean proved to be the same or 25.4 in five rural municipalities in 1846-49 (Varis 1971). Eastern Finland was represented by the rural municipalities of Kitee in Karelia, where the mean was 24.5 (Information received by Kari Pitkänen). 
After the baby-boom in post-war Finland in 1946- 50 , fertility began to decrease again but by the end of the 1950 s it had not yet reached the same low level as in the 1930s.

T a ble 5. Complete fertility per woman based on cross-sectional age specific fertility rates, 1865-1960.

$\begin{array}{llll}1851-55 & 4.92 & 1906-10 & 4.65 \\ 1856-60 & 4.76 & 1911-15 & 4.16 \\ 1861-65 & 5.03 & 1916-20 & 3.48 \\ 1866-70 & 4.34 & 1921-25 & 3.32 \\ 1871-75 & 4.90 & 1926-30 & 2.90 \\ 1876-80 & 4.96 & 1931-35 & 2.40 \\ 1881-85 & 4.85 & 1936-40 & 2.40 \\ 1886-90 & 4.92 & 1941-45 & 2.60 \\ 1891-95 & 4.66 & 1946-50 & 3.37 \\ 1896-1900 & 4.82 & 1951-55 & 2.97 \\ 1901-05 & 4.71 & 1956-60 & 2.78\end{array}$

Source: Strömmer 1969, 50 and Turpeinen 1979, 102.

In order to compare fertility with the results of other studies, we have used Coale's index of marital fertility $I_{g}=\frac{B}{\Sigma m_{i} F_{i}}$. In this index $\Sigma m_{i} F_{i}$ is the same as in $I_{m}$ and $B$ the number of annual legitimate live births. ${ }^{5}$

This index relates the annual number of legitimate live births to the number of legitimate births that would occur to married women if they were subjected to natural fertility.

Marital fertility measured by this index was in 1910 about eight per cent lower than in 1900 when it reached its highest level, and in 1960 about one half of that (Table 6).

$\mathrm{T}$ a ble 6 . Index of marital fertility on the national level in $1880-1960$.

$\begin{array}{llll}1880 & 0.703 & 1930 & 0.546 \\ 1890 & 0.693 & 1940 & 0.404 \\ 1900 & 0.703 & 1950 & 0.429 \\ 1910 & 0.646 & 1960 & 0.336 \\ 1920 & 0.543 & & \end{array}$

Compared with some Western European marital fertility indices, Finnish fertility seems to have been somewhat lower in the beginning of the industrial-

5 The number of births used here is the mean of the three years around the census year. 
izing period. In 1880 when industrialization in Western Europe had already reached a much higher level than in Finland the $I_{\mathrm{g}}$ in Germany was still 0.735 , in Belgium 0.751 and in the Netherlands 0.813 . In these countries fertility began to diminish in the 1870 s or earlier and this tendency, which was faster than in Finland, continued after 1880. In 1910 Belgium shows an index value of 0.443 , Germany 0.542 and the Netherlands 0.622 . In France fertility was considerably lower during the whole period; in 1880 it was already as low as 0.460 and in 1910 it was only 0.314 (Lesthaeghe 1974, 102).

Complete fertility based on cross-sectional age specific rates in the three local municipalities from 1850 to 1930 shows great fluctuation from year to year (Figure 3). In Pohja the peak is reached in the middle of the 1890s. In Sysmä fertility follows a much smoother pattern than that of Pohja, and was quite low until the 1910s. It was still lower in Hamina. In the 1920s Pohja and Ha-

Figure 3. Complete period fertility in Pohja, Sysmä and Hamina in $1880-1930.1$

Children

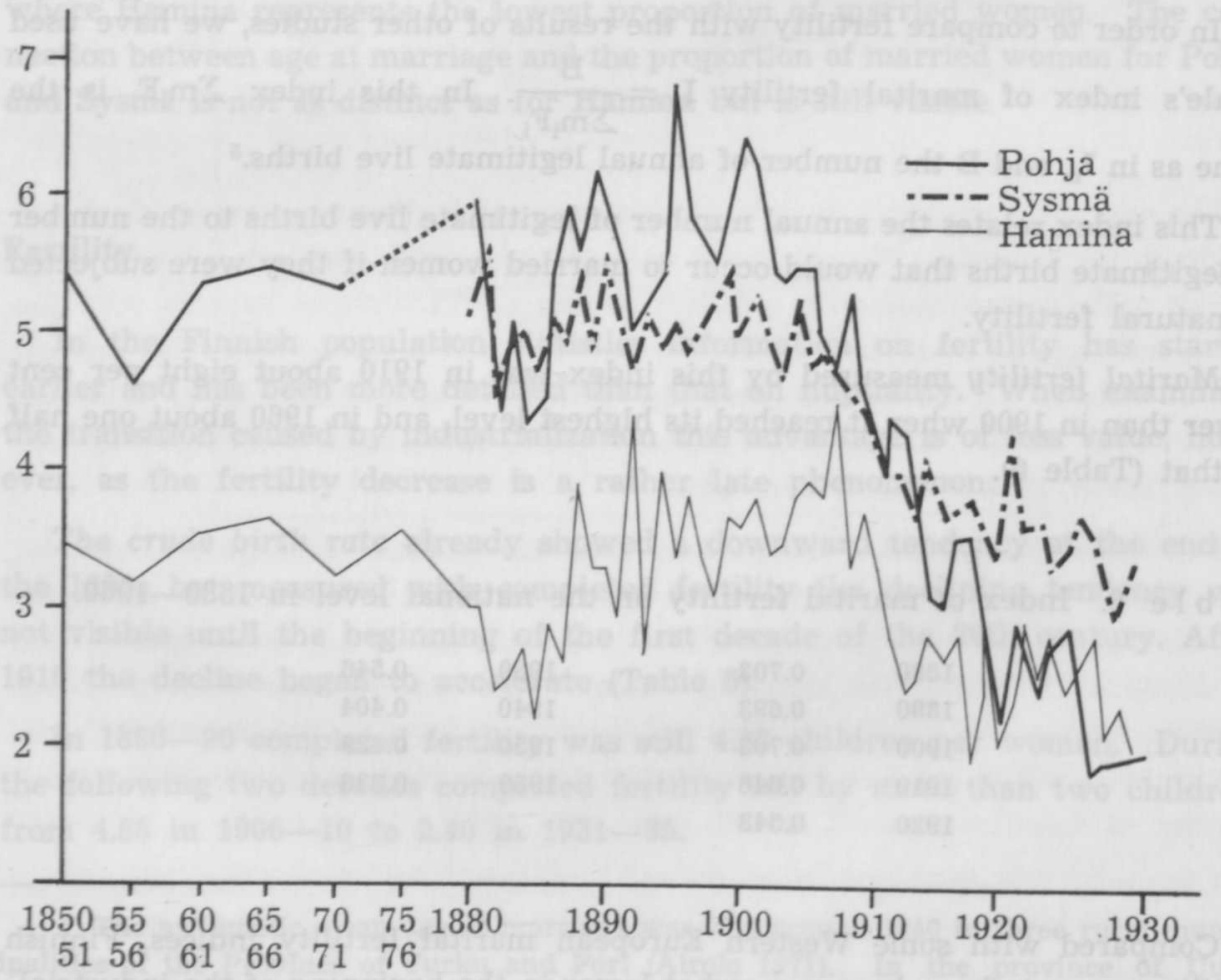

1 Based on fertility data of the whole parish. During $1850-1879$ the rates are the averages of two successive years with five-year intervals, from 1880 on the rates are calculated separately for every year. 
mina reached the same relatively low level while Sysmä remained on a clearly higher level.

It is not easy to find invariances in the up and down movements of the development in the three municipalities. However, fertility seems to have begun to decrease in Pohja during the first years of the 20th century and in Sysmä some years later and in Hamina towards 1910. The great fluctuations in Pohja are most likely to have been caused by business cycles to which Pohja was very susceptible as most of the families included in the family reconstruction study were more or less dependent on the profit of the ironworks in the community.

The marital fertility index in the three local municipalities shows the same evolution as the national average (Table 7). Fertility increased until the end of the 19th century and began to decrease after that. The highest index of marital fertility is found in 1900 in Pohja and Hamina while Sysmä reaches its peak ten years later. In Sysmä fertility was higher than the national average during the whole period investigated, which seems to be quite logical; Sysmä was still a typical agrarian society in the 1960 s. Pohja also displays a higher marital fertility than the country mean until the beginning of the 20th century; after that it sank to a lower level than the national mean.

It should be mentioned that Hamina does not represent a typical expanding urban municipality in the period of growing urbanization. In urban and rural municipalities the average general fertility remained unchanged during the period 1880-1910, if one disregards small annual variations. In 1880 rural fertility was 0.149 per woman and urban fertility was 0.089 ; in 1910 figures were 0.143 and 0.089 . After this year the difference between rural and urban fertility started to diminish but in 1950 fertility in the rural municipalities was still twice as high as in the urban ones; in 1960 the difference had shrunk to one fifth; the annual general fertility was now 0.052 and the urban 0.067 .

$\mathrm{Table}$ 7. Index of marital fertility $\left(\mathrm{I}_{\mathrm{g}}\right)$ in Pohja, Sysmä and Hamina.

$\begin{array}{lccc} & \text { Pohja } & \text { Sysmä } & \text { Hamina } \\ 1880 & 0.872 & 0.868 & 0.670 \\ 1890 & 0.817 & 0.840 & 0.597 \\ 1900 & 0.848 & 0.844 & 0.699 \\ 1910 & 0.650 & 0.911 & 0.544 \\ 1920 & 0.502 & 0.797 & 0.474 \\ 1930 & 0.389 & 0.627 & 0.367 \\ 1940 & 0.272 & 0.532 & 0.359 \\ 1950 & 0.299 & 0.546 & 0.377 \\ 1960 & 0.264 & 0.293 & 0.309\end{array}$




\section{Aspects and conclusions}

Nuptiality and fertility changes seem to follow the same pattern of development in the beginning of industrialization in Finland. The decrease of nuptiality measured with the index of proportion married, could probably be said to have began somewhat earlier than the decline of fertility: nuptiality declined after 1890 but fertility did not until 1900. In broad outlines the decrease of both phenomena coincide until 1920. After that nuptiality turned upwards but fertility continued to decrease (Figure 4).

The decrease in proportion of married women during the first phase of the Industrial Revolution constitutes a phenomenon diverging from the evolution of nuptiality in Western Europe. In general, better economic facilities for a growing number of people and a gradually extended control of fertility in the industrialized society implied a tendency toward earlier and more universal marriage. In Belgium, which has been referred to many times in this article as a typical Western European country, nuptiality started its upward movement already in the 1850 s. This increasing trend continued for a century.

Figure 4. Evolution of the proportion of married women and the proportion of marital fertility in 1880-1960.

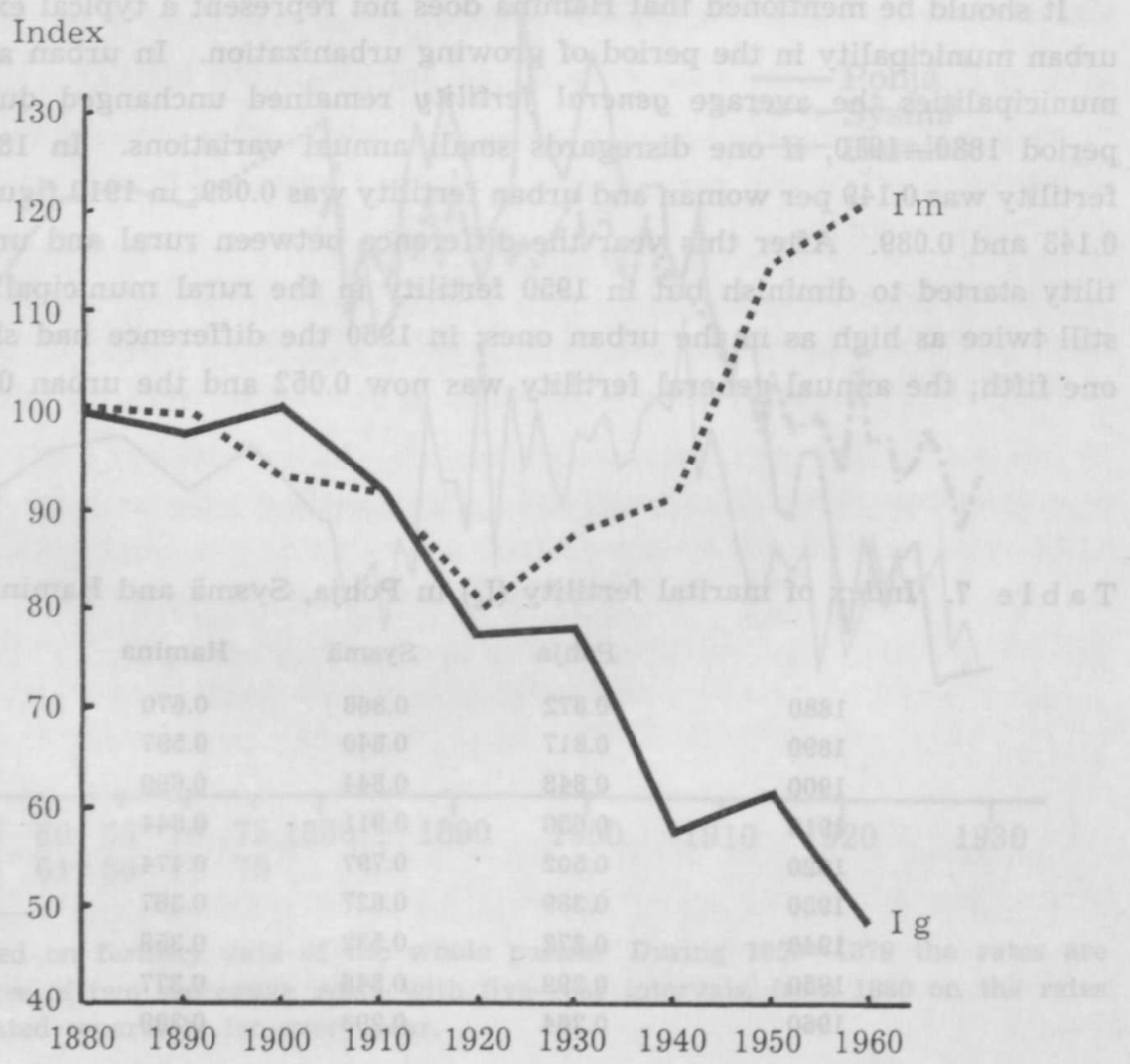


In spite of some variations and divergences due to different economic and social development, the marital fertility and the proportion of married women in the three municipalities studied follow the same pattern as the national average.

This decline in marriage frequency in Finland at the end of the 19th century has been explained by the ceasing influence of the village endogamy on persons who had moved away from their birthplaces in rural municipalities to towns or cities (Hartman 1958, 71). In the old agrarian society the village endogamy was very marked. Marriage was usually contracted with a partner from the same or neighboring village and the rules did not lose their effect even when people, mostly young and unmarried, migrated to urban municipalities. The growth of the urban population was rather intensive at the end of the 19th century: from 1880 to 1900 the proportion of the urban population increased from 8.5 per cent to 12.5 per cent. Even before the breakthrough of industrialization geographical mobility had been rather common, mainly to neighboring municipalities and often only for a year or two. In the pre-industrial period the migrant seldom changed his profession. Industrialization often meant a new occupation for the migrant in an urban environment and that he settled down more or less permanently.

The reasons for the marked endogamy could be the low population density that has kept subcultures alive and hindered intercourse with people living in other regions and even neighboring communities. This was the case at least with the Swedish- and Finnish-speaking population living side by side on the southern and western coast of Finland.

The last decades of the 19th century are usually considered as a period characterized by rapid social, cultural and economic development. This period of peaceful societal evolution ended at the beginning of the following century in "the years of oppression» when the Russification drive began to nullify the relative independence Finland had as autonomous Grand Duchy of the Russian Empire. A state of insecurity characterized these years. The resistance against Russification resulted among other things in a nation-wide strike which was in many respects the awakening of the Finnish people (Siipi 1967, 13). Now the national feeling of the Finnish-speaking population gained ground and the political labor movement expanded. Further, the one-chamber parliament was established instead of the former Diet of four estates and women gained universal suffrage.

It is most probable that these years of insecurity in the beginning of the century contributed to diminishing marriage frequency and fertility. It is further likely that the profound social changes, national integration and the democratization process contributed to opening the minds of the common people to new ideas such as the concept of a new smaller family ideal typical of the industrialized society. Hence, the great societal transition, more than the years of unrest is likely to have given the impetus to the decreasing fertility trend that began in the first decade of the 20th century. 
From 1920 to 1930 the decreasing nuptiality trend changed direction and turned to an increase. In 1960 the proportion of married women was 50 per cent higher than in 1920 . In the 1930 s the deep recession suppressed somewhat the propensity to marry but it could not break off the tendency to a growing nuptiality. After the Second World War growth accelerated especially due to the fact that early marriages became more common partly at least because society created social conditions for early marriages (Sihvo 1976, 53). From the end of the 1930 s when the age at marriage was higher than ever since the beginning of industrialization or 24.7 years it sank to 22.8 at the end of the 1950 s.

Due to economic progress the norms concerning the economic requirements of marriage were broken down. Marriage did not affect the economy of the household as much as it had earlier (Piepponen 1964, 10). Even the sectorization of society has promoted the growth in popularity of nuptiality. People need more emotional contacts and they found them in marriage (Sihvo 1976, 53).

In conclusion nuptiality in Finland seems to have followed a pattern that diverges from that of Western Europe. The proportion of married women declined during the first decades of this century. As a consequence fertility decreased somewhat as the general fertility rate also proves. However, after 1910 the decreasing trend was strengthened. The proportion married started its upward movement in 1920. This tendency continued until the end of the period studied when nuptiality and fertility in Finland reached about the same level as in Western Europe.

\section{References}

Airola, Leena: Morsianten ikä ja aviopuolisoiden sosiaalinen valinta eräissä LounaisSuomen seurakunnissa 1753-1843. Unpublished pro gradu thesis. Helsingin yliopisto. Historian laitos. 1971.

Coale, Ansley J.: Factors associated with development of low fertility, an historic summary. World Population Conference. Volume 2. New York 1965.

Coale, Ansley J. - Andersson, Barbara - Härm, Erna: Human Fertility in Russia since the Nineteenth Century. New Jersey 1979.

Hajnal, J.: European Marriage Patterns in Perspective. In Population in History, ed. by D. V. Glass and D. E. C. Eversley. London 1965.

Hartman, Tor: Nuptiality and Social Structure. Transactions of the Westermarck Society Vol. IV No 2. Copenhagen 1958.

Hjerppe, Riitta - Pihkala, Erkki: Bruttokansantuote Suomessa 1860-1913. Alustava arvio. Kansantaloudellinen aikakauskirja 3/1977.

Lesthaeghe, Ron J.: The Decline of Belgian Fertility 1800-1970. New Jersey 1977.

Mathias, Peter: The First Industrial Nation. An economic history of Britain 1700-1914. London 1969.

OSF (Official Statistic of Finland): Väkiluvun-Tilastoa VI. Pääpiirteet Suomen Väestötilastosta vuosilta $1750-1890$. Helsinki 1909.

Piepponen, Paavo: Early marriage in Finland, 1878-1960. Publication of the Population Research Institute, Series B, No 1, 1964. Helsinki 1964.

Rostow, W. W.: The Stages of Economic Growth. Cambridge 1971. 
Sihvo, Jouko: Avioliitto ja avioero. Kirkontutkimuslaitos. Sarja A N:o 30 . Vammala 1976.

Siipi, Jouko: Ryysyrannasta hyvinvointivaltioon. Sosiaalinen kehitys itsenäisessä Suomessa. Helsinki 1967.

Strömmer, Aarno: Väestöllinen muuntuminen Suomessa. Väestöpoliittisen tutkimuslaitoksen julkaisuja A: 13. Tornio 1969.

Turpeinen, Oiva: Fertility and Mortality in Finland since 1750. Population Studies. Volume 33. Number 1. London 1979.

Varis, Terttu: Ensimmäisen avioliittonsa solmineiden naisten avioituminen Uudellamaalla 1700 -luvun puolivälistä 1800 -luvun puoliväliin. Unpublished pro gradu thesis. Helsingin yliopisto. Historian laitos 1971. 